\title{
Leptin induces inflammation-related genes in RINm5F insulinoma
} cells

\author{
Paul Hekerman ${ }^{1}$, Julia Zeidler ${ }^{1}$, Stefanie Korfmacher ${ }^{1}$, Simone Bamberg- \\ Lemper $^{1}$, Holger Knobelspies ${ }^{1}$, Lennart Zabeau ${ }^{2}$, Jan Tavernier ${ }^{2}$ and \\ Walter Becker*1
}

\begin{abstract}
Address: ${ }^{1}$ Institute of Pharmacology and Toxicology, Medical Faculty of the RWTH Aachen University, Wendlingweg 2, 52074 Aachen, Germany and ${ }^{2}$ The Flanders Interuniversity Institute for Biotechnology, Department of Medical Protein Research (VIB9), Ghent University, Faculty of Medicine and Health Sciences, A. Baertsoenkaai 3, 9000 Ghent, Belgium

Email: Paul Hekerman - paul.hekerman@web.de; Julia Zeidler - Julia-zeidler@gmx.de; Stefanie Korfmacher - skorfmacher@web.de; Simone Bamberg-Lemper - sbamberg-lemper@ukaachen.de; Holger Knobelspies - hknobelspies@gmx.de;

Lennart Zabeau - Lennart.Zabeau@UGent.be; Jan Tavernier - jan.tavernier@UGent.be; Walter Becker* - wbecker@ukaachen.de

* Corresponding author
\end{abstract}

Published: 23 May 2007

BMC Molecular Biology 2007, 8:4| doi:10.| |86/|47|-2|99-8-4 |

This article is available from: http://www.biomedcentral.com/l47I-2199/8/4I

(c) 2007 Hekerman et al; licensee BioMed Central Ltd.

This is an Open Access article distributed under the terms of the Creative Commons Attribution License (http://creativecommons.org/licenses/by/2.0), which permits unrestricted use, distribution, and reproduction in any medium, provided the original work is properly cited.

\begin{abstract}
Background: Leptin acts not only on hypothalamic centers to control food intake but has additional functions in peripheral tissues, e.g. inhibition of insulin secretion from pancreatic islets. The leptin receptor (LEPRb) is a class I cytokine receptor that mediates activation of STAT transcription factors. In this study, we characterise the regulation of inflammation-related genes by leptin in insulinoma cells and compare the effect of transcriptional regulation by leptin with that of other cytokines.
\end{abstract}

Results: We have used RINm5F insulinoma cells as a model system for a peripheral target cell of leptin. Six transcripts encoding inflammation-related proteins were found to be upregulated by activation of LEPRb, namely lipocalin-2, pancreatitis-associated protein, preprotachykinin-I, fibrinogen- $\beta$, tissue-type plasminogen activator (tPA) and manganese-dependent superoxide dismutase (MnSOD). Four of these transcripts (fibrinogen- $\beta$, lipocalin-2, tPA, MnSOD) were also induced by the proinflammatory cytokine interleukin-I $\beta$ (IL-I $\beta$ ). Interferon- $\gamma$ alone had no effect on the leptin-induced transcripts but enhanced the upregulation by IL-I $\beta$ of lipocalin-2, tPA and MnSOD mRNA levels. Experiments with LEPRb point mutants revealed that the upregulation of the inflammation-related genes depended on the presence of tyrosine-1 I 38 which mediates the activation of the transcription factors STATI and STAT3. Reporter gene assays showed that leptin induced the expression of preprotachykinin-I and lipocalin-2 on the level of promoter regulation. Finally, leptin treatment increased caspase 3-like proteolytic activity in RINm5F cells.

Conclusion: The present data show that leptin induces a cytokine-like transcriptional response in RINm5F cells, consistent with the proposed function of leptin as a modulator of immune and inflammatory responses. 


\section{Background}

Leptin is a cytokine which is secreted predominantly by white adipose tissue and exerts its effects on appetite and thermogenesis on centers located in the hypothalamus [1]. In addition to these well defined central actions, it has become clear that leptin also has important peripheral effects, including the regulation of the immune system and the modulation of insulin secretion from the pancreas [2-4]. The requirement of leptin for a normal immune response has been characterised in detail in various animal models of autoimmune diseases and experimentally induced inflammation $[5,6]$. This proinflammatory effect of leptin is at least partially mediated by its direct action on T-lymphocytes, although macrophages and natural killer (NK) cells also appear to be responsive to leptin [5-7].

Two main signalling pathways have been proposed to mediate the inhibitory effect of leptin on insulin secretion. Firstly, leptin causes the PI-3 kinase-dependent activation of phosphodiesterase $3 \mathrm{~B}$ (PDE3B) and subsequent reduction of intracellular cAMP levels [8]. Secondly, leptin activates ATP-sensitive $\mathrm{K}^{+}$channels on $\beta$-cells and thereby antagonises depolarisation required for insulin secretion [9]. These are both unusual pathways, considering that the leptin receptor (LEPR) belongs to the class I cytokine receptor family and transmits signals mainly via the JAK/STAT (Janus kinase/signal transducer and activator of transcription) pathway [10]. LEPR exists in several splicing variants, the longest one (LEPRb) being the only one capable of activating JAK/STAT signalling $[11,12]$. The effect of leptin on $\beta$-cells clearly depends on the presence of the long splicing variant of the leptin receptor (LEPRb), because leptin does not inhibit insulin secretion from islets isolated from $d b / d b$ mice which harbour a splice site mutation that specifically affects expression of LEPRb [13]. Ligand binding to LEPRb results in trans-autophosphorylation and thereby activation of the receptor-associated tyrosine kinase JAK2 and subsequent recruitment and activation of STAT factors to phosphorylated tyrosine residues in the cytoplasmic part of LEPRb $[10,14]$. In rat islet cells and in rodent insulinoma cell lines (RINm5F, MIN6), leptin has been shown to stimulate tyrosyl phosphorylation of STAT1, STAT3, STAT5 and dual phosphorylation of the MAP kinases ERK1/2 [15-18]. We have recently shown that each of the three conserved tyrosine residues in murine LEPRb exhibits different signalling capacities in the insulinoma cell line HIT-T15 [18]. Tyr985 mediated leptin-induced activation of extracellular signal-regulated kinases 1 and 2 (ERK1/2), Tyr1077 induced tyrosyl phosphorylation of STAT5, and Tyr1138 was capable of activating STAT1, STAT3, and STAT5. Although STAT factors are well known to regulate transcription, the range of transcriptional targets responsive to leptin stimulation of pancreatic $\beta$-cells is not well characterised [19].

In the present study we used rat RINm5F insulinoma cells as a model system to study the changes in gene expression that leptin elicits in $\beta$-cells and to characterise the signalling pathway(s) by which the transciptional effects of leptin are mediated. In particular, we show that several inflammation-related genes were upregulated by leptin. Notably, some of these mRNAs were also induced by IL$1 \beta$, a pro-inflammatory cytokine thought to play a major role in $\beta$-cell destruction in type 1 diabetes mellitus. These data provide the first characterisation of leptin's effects on gene expression in a non-neuronal cell type.

\section{Results \\ Identification of leptin-induced genes in RINm5F cells}

We have previously employed RINm5F cells ectopically expressing LEPRb to characterise leptin signal transduction in an insulin-producing cell line [18]. In order to identify genes regulated by leptin in pancreatic $\beta$-cells, we compared gene expression in leptin-stimulated and nonstimulated RINm5F cells by differential hybridisation of high-density filter arrays containing 27,648 non-redundant rat cDNAs. From 33 transcripts that showed a strong differential signal after $16 \mathrm{~h}$ of leptin treatment, we selected 13 for further expression analysis by Northern blot hybridisation. Table 1 lists 8 transcripts that were confirmed to be upregulated by leptin. Five transcripts were identified as false positives (see Additional file 1 for the complete list).

In this study we focus on those genes potentially related to inflammatory processes. Four transcripts encode secreted acute phase proteins: fibrinogen- $\beta$, tissue-type plasminogen activator (tPA), pancreatitis-associated protein (PAP1), and lipocalin-2 [20]. Preprotachykinin-1 is the precursor of substance $\mathrm{P}$, a mediator of neurogenic inflammation [21]. In addition, the mitochondrial enzyme manganese-dependent superoxide dismutase (MnSOD) has also been classified as an "acute phase protein" because it is upregulated in many inflammatory conditions [22].

\section{Costimulatory effects of IL-I $\beta$ and leptin}

Considering that interleukin- $1 \beta$ (IL-1 $\beta$ ) is an important inflammatory mediator in pancreatic $\beta$-cells, we asked whether leptin and IL-1 $\beta$ had overlapping effects on the expression of inflammation-related genes. Therefore, RINm5F cells were stimulated with IL-1 $\beta$, leptin, or a combination of leptin and IL-1 $\beta$ for different time periods, and mRNA levels of specific transcripts were analysed by Northern blotting (Figure 1). As controls, we used probes for iNOS, which is known to be induced by IL-1 $\beta$, and ribosomal protein L4 (RPL4) as a loading control. 
Table I: List of transcripts upregulated by $16 \mathrm{~h}$-leptin treatment in RINm5F cells

\begin{tabular}{|c|c|c|c|c|c|c|}
\hline & \multirow[b]{2}{*}{ Gene symbol* } & \multirow[b]{2}{*}{ GenBank Accession. } & \multirow[b]{2}{*}{ UniGene } & \multicolumn{2}{|c|}{ Signal intensities ${ }^{\dagger}$} & \multirow[b]{2}{*}{$\begin{array}{c}\text { Fold induction by } \\
\text { leptin }\end{array}$} \\
\hline & & & & mock & leptin & \\
\hline Phosphatidate phosphohydrolase $2 \mathrm{a}$ & Ppap2a & Al555126 & Rn.6I687 & 0.3 & 2.4 & 8.9 \\
\hline Regulator of G-protein signaling 4 & Rgs4 & Al502324 & Rn.II065 & 3.2 & 16.9 & $5.2 \ddagger$ \\
\hline Preprotachykinin I & Tacl & AA818532 & Rn. 1920 & 44.6 & 188.2 & 4.2 \\
\hline Fibrinogen, beta polypeptide & Fgb & Al059690\$ & Rn.II4I6 & 3.0 & $\mathrm{II} .4$ & $3.8 \S$ \\
\hline Plasminogen activator, tissue-type (tPA) & Plat & AA875008 & Rn. 107102 & 2.3 & 7.7 & 3.3 \\
\hline Lipocalin 2 & $\operatorname{Len} 2$ & All 37617 & Rn.II303 & 2.7 & 8.7 & 3.2 \\
\hline Pancreatitis-associated protein (PAPI) & $P a p$ & AA998280 & Rn.9727 & 1.9 & 5.5 & 2.9 \\
\hline superoxide dismutase 2 (MnSOD) & Sod2 & Al029806 & Rn. 10488 & 17.1 & 48.3 & 2.8 \\
\hline
\end{tabular}

* Official gene symbol in the Rat Genome Database

t Phosphoimager evaluation of filter array hybridization (relative units corrected to background and normalized to $\beta$ actin

¥ Representative of four different Rgs4 cDNA clones (ratios: 5.2, 2.9, 2.8 and 2.4).

$\S$ Representative of two different fibrinogen- $\beta$ cDNA clones (ratios: 3.8 and 2.8).

According to the different time courses of leptin-induced upregulation, Northern blot analysis allowed us to distinguish immediate early (fibrinogen- $\beta$ ), delayed early (PAP1) and late target genes (lipocalin-2, preprotachykinin, tPA, MnSOD, and phosphatidate phosphohydrolase 2a/PPAP2A), which had their expression maxima at 1-3 $\mathrm{h}, 7 \mathrm{~h}$ and $16 \mathrm{~h}$ of leptin stimulation, respectively. Concerning the effect of IL- $1 \beta$, mRNA levels for fibrinogen- $\beta$, tPA, lipocalin2, MnSOD and PPAP2A were found to be upregulated by IL-1 $\beta$ alone. Among them, lipocalin 2 and MnSOD were more strongly induced by IL1 $\beta$ than by leptin. As expected, iNOS mRNA was induced by IL-1 $\beta$ but not by leptin. Costimulation with IL1 $\beta$ and leptin revealed synergistic effects of both cytokines on the expression of fibrinogen- $\beta$, lipocalin- 2 and MnSOD, i.e. the effect of costimulation exceeded the added effects of each cytokine.

\section{Comparison of leptin and IFN $\gamma$}

It is well known that IL-1 $\beta$ and IFN $\gamma$ synergistically regulate inflammation-related genes in pancreatic $\beta$-cells [23]. Since both leptin and IFN $\gamma$ modulate gene expression by activating the JAK/STAT pathway, we compared the effects of these cytokines on the activation of STAT factors in the RINm5F cell line. As we have previously reported [16], leptin induced tyrosyl phosphorylation of both STAT3 and STAT1 (Figure 2). In contrast, IFN $\gamma$ rather selectively activated STAT1. Although in this direct comparison IFN $\gamma$ elicited a stronger tyrosyl phosphorylation of STAT1, this result hints to the possibility that both cytokines have partially overlapping effects on gene expression in RINm5F cells.

Next we analysed the effects of leptin and IFN $\gamma$ on the expression of the inflammation-related transcripts identified in the present study. RINm5F cells were stimulated with leptin or IFN $\gamma$ either alone or in combination with
IL-1 $\beta$, and transcript levels were determined by Northern blot hybridisation. A probe for IFN $\gamma$-regulated factor 1 (IRF1) was included as a positive control for the action of IFN $\gamma$. As shown in Figure 3, IFN $\gamma$ alone did not upregulate the transcripts that were induced by leptin. On the other hand, IRF1 mRNA levels were not affected by leptin. These results show that leptin and IFN $\gamma$ differentially regulate the expression of inflammation-related genes in RINm5F insulinoma cells, probably because the cytokines act via different STAT factors. Interestingly, similar to leptin, IFN $\gamma$ enhanced the IL-1 $\beta$-induced upregulation of the mRNAs for tPA, lipocalin-2 and MnSOD.

\section{Requirement of Tyr-I I38 in LEPRb for induction of inflammation-related genes}

Next, we asked which signalling pathway might be involved in the induction of the inflammation-related genes by leptin. To determine the role of the three intracellular tyrosine residues (Tyr985, Tyr1077, Tyr1138) in LEPRb-mediated activation of gene expression, we generated RINm5F cell lines that stably express LEPRb point mutants in which phenylalanines replace two of the three tyrosines, or the triple mutant. Leptin binding assays verified that all LEPRb constructs were expressed at the cell surface and differed by less than 2.2-fold in leptin binding (surface binding sites of mutant receptors relative to the wild type receptor: FFY, $1.10 \pm 0.05$; FYF $1.4 \pm 0.06$; YFF, $2.01 \pm 0.13$; FFF, $2.13 \pm 0.47$; for designations of the LEPRb mutants see Figure 4).

To characterise the signalling potential of these cells, we analyzed the leptin-induced phosphorylation of STAT factors and of ERK1/2 by Western blotting with activation state-specific antibodies (Figure 4). The results show that the full activation of STAT1 and STAT3 required the presence of Tyr1138, whereas the phosphorylation of STAT5 was mediated equally well by Tyr1077 and Tyr1138. The 


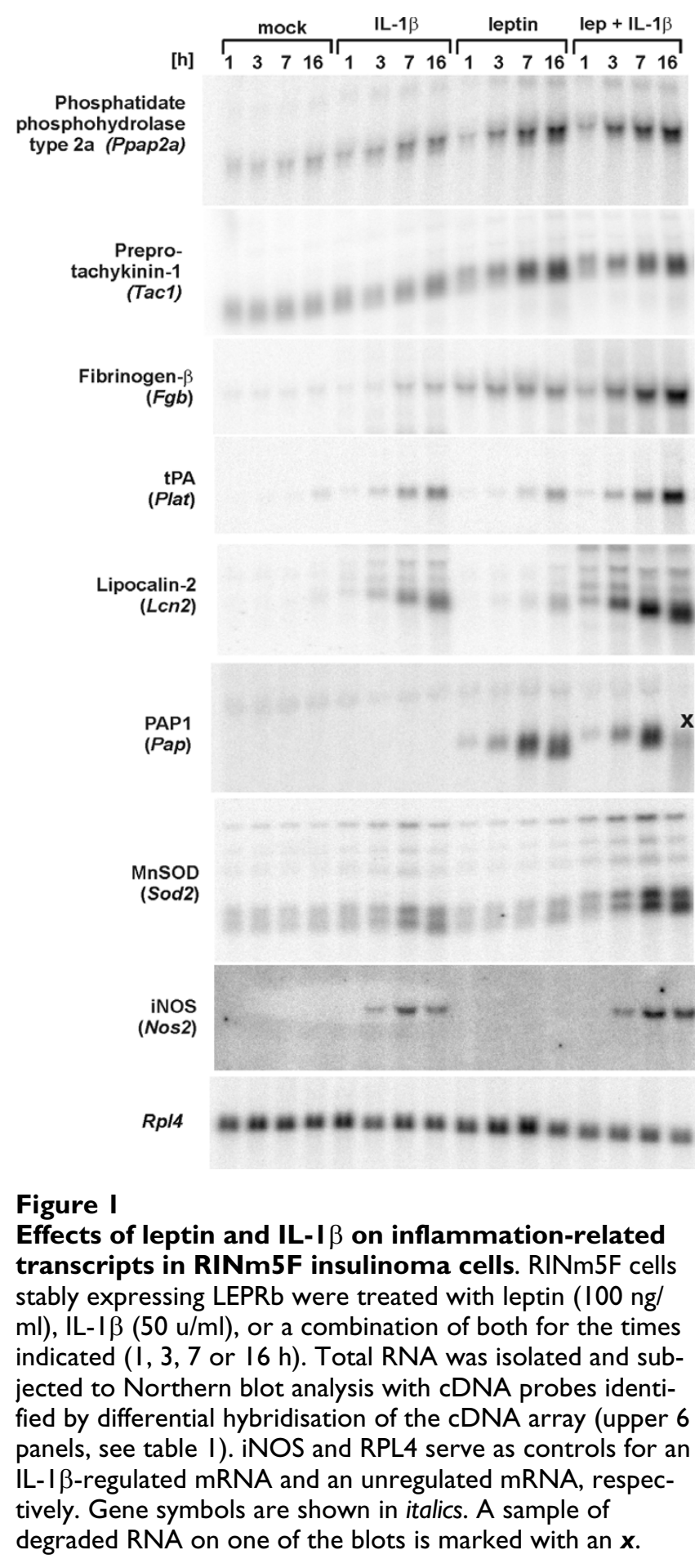

major part of ERK phosphorylation was dependent on the membrane-proximal tyrosine residue (Tyr985). These findings are in agreement with results that we have previously obtained in transiently transfected HIT-T15 insulinoma cells [18]. Intriguingly, a residual phosphorylation of STAT factors and of ERK1/2 was detectable even when

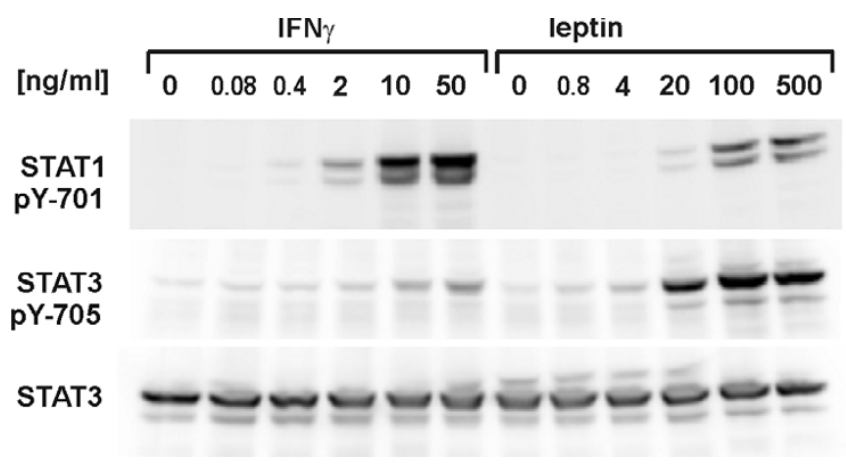

Figure 2

Activation of STATI and STAT3 by leptin and IFN $\gamma$. RINm5F cells stably expressing LEPRb were stimulated with the indicated concentrations of IFN $\gamma$ or leptin for $15 \mathrm{~min}$. Tyrosyl phosphorylation of STATI and STAT3 was determined by Western blot analysis of total cellular lysates with activation state-specific antibodies. The two bands reacting with the PTyr(705)-STATI antibody represent the splice variants STATI $\alpha(9 \mid \mathrm{kD})$ and STATI $\beta(84 \mathrm{kD})$. The lower band detected by the STAT3 antibodies is probably the splice variant STAT3 $\beta$. Total STAT3 immunoreactivity is shown as a control.

all intracellular LEPRb tyrosine residues had been exchanged for phenylalanine. This cannot be explained by the action of endogenous LEPRb since neither the parental RINm5F cells nor control cells that were infected with the empty vector showed detectable effects of leptin (data not shown).

These cell lines were now used to study the capacity of the LEPRb point mutants to upregulate mRNA levels of the leptin target genes identified in this work. As shown in Figure 5, induction by leptin depended on the presence of Tyr1138, suggesting that the transcription of these genes is regulated by STAT3 and/or STAT1. Consistent with the tyrosine-independent activation of STAT3 detected by Western blotting (Figure 4), weak leptin effects were also observed in the cell lines expressing LEPRb-YFF or LEPRbFYF. However, the degree of induction by these constructs did not exceed that of the triple mutant (FFF). Interestingly, transcript levels were always higher in cells expressing LEPRb-FFY compared to wild type LEPRb, consistent with a role for Tyr985 and Tyr1077 in the negative regulation of leptin signalling $[24,28]$.

\section{Leptin controls preprotachykinin-I and lipocalin-2 gene expression at the level of promoter regulation}

To substantiate the hypothesis that leptin controls the expression of inflammation-related genes by way of transcriptional regulation, we decided to determine the effect of leptin on promoter activity. We selected two rat genes whose promoters had not previously been analysed for 


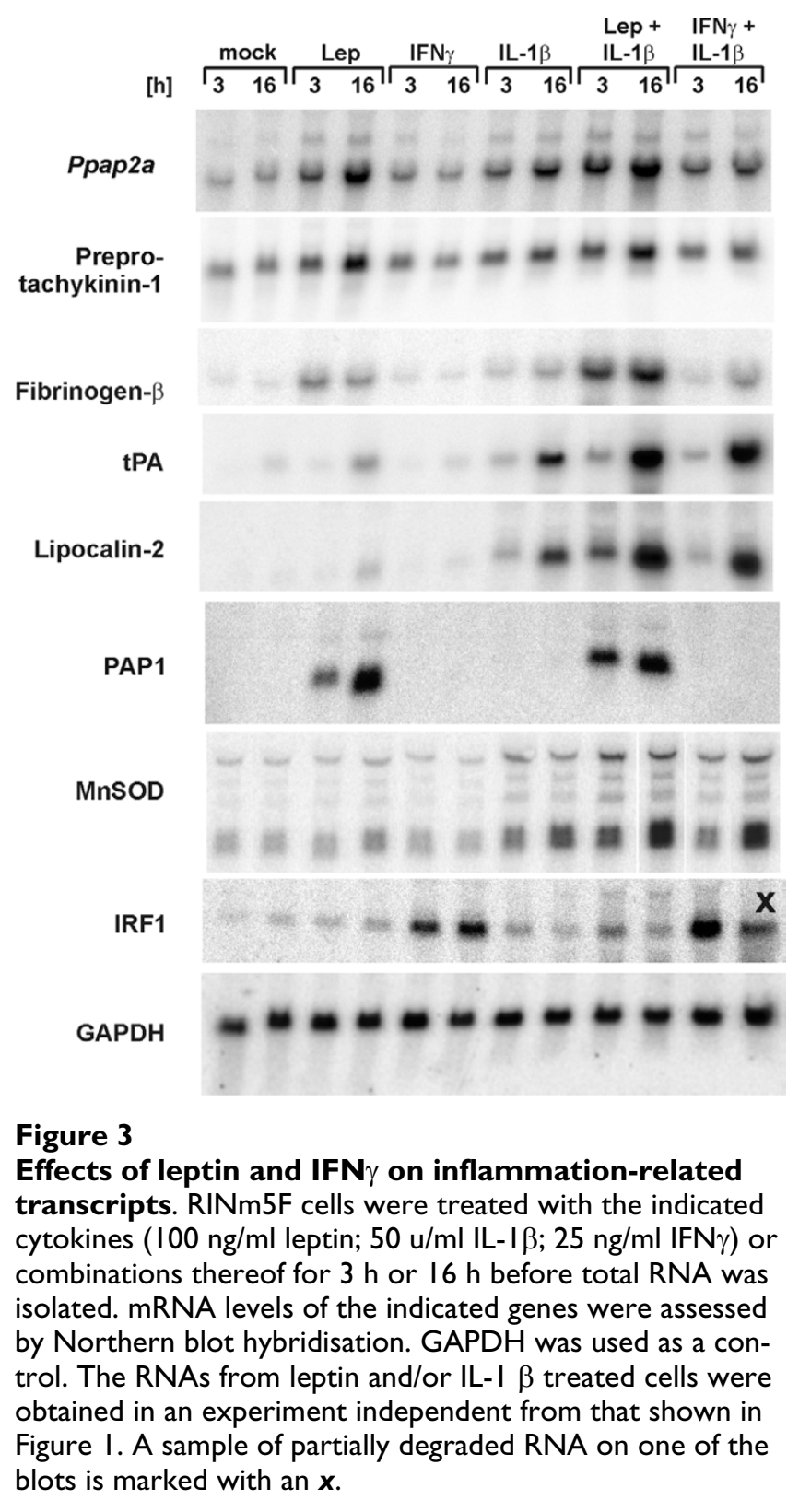

regulation by STAT factors, Lcn2 (encoding lipocalin-2) and Tac1 (preprotachykinin-1). As in our previous studies [18], we used HIT-T15 hamster insulinoma cells for the promoter assays because RINm5F cells were only poorly transfected in transient assays. The results of the luciferase assays are presented in Figure 6 and show clearly that both the Lcn2 and the Tac1 promoter are regulated by leptin. Consistent with the Northern blot results, promoter induction depended on the presence of Tyr1138 in LEPRb, supporting the hypothesis that STAT1 and/or STAT3 are involved. Also in agreement with the Northern blot data, Lcn 2 promoter activity was very low in the absence of leptin and was strongly induced by leptin,

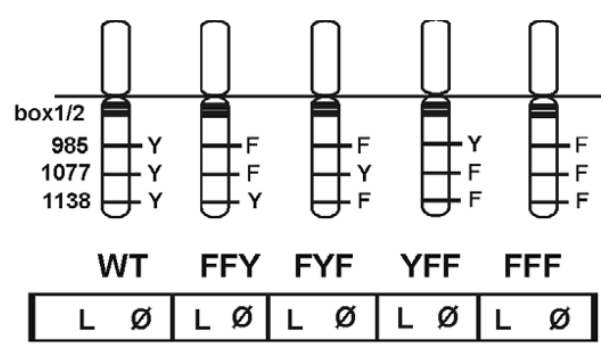

STAT1

pY-701

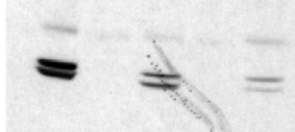

STAT3

pY-705

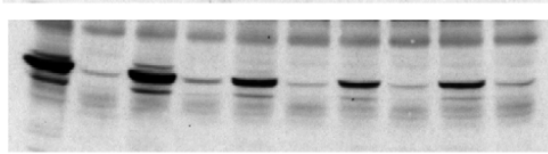

STAT5A/B

pY-694/699

ERK1/2

pT183
pY185

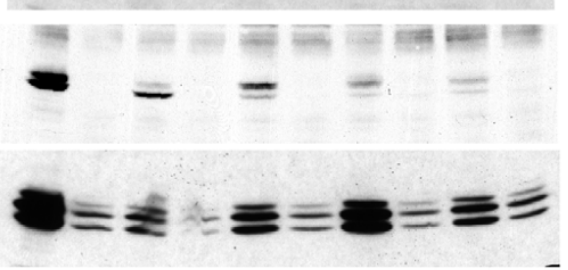

\section{Figure 4}

Signalling capacity of RINm5F cells expressing

LEPRb point mutants. RINm5F cells stably expressing the wild type LEPRb (YYY) or the indicated LEPRb tyrosine/phenylalanine mutants were treated with $100 \mathrm{ng} / \mathrm{ml}$ leptin $(\mathrm{L})$ or vehicle $(\varnothing)$ for 15 min before total cell lysates were pre-

pared. Leptin-induced phosphorylation of downstream signalling molecules was assayed by Western blotting and immunodetection with phospho-specific antibodies.

whereas the Tac1 promoter showed considerable basal activity in the absence of a stimulus. These data indicate that leptin upregulates expression of lipocalin-2 and preprotachykinin- 1 by control of transcription.

To address the question whether the regulation of these promoters by leptin was a specific feature of insulinoma cells, we took advantage of a LEPRb-expressing PC-12 pheochromocytoma cell line that was established in a previous study [25]. In this cell line, the effect of leptin on target gene promoters was found to be enhanced by simultaneous treatment with forskolin. Forskolin is a nonspecific activator of adenylate cyclases and enhances intracellular levels of cAMP. Similar to the results obtained in HIT-T15 cells transfected with wild type LEPRb, leptin induced both the Tac1 and the Lcn 2 promoter in the PC-12 cell line (Figure 7). The weaker effect of leptin as compared to the HIT-T15 cells is likely due to the fact that the PC-12 cells were not kept serum-free during treatment with leptin and/or forskolin, in order to avoid differentiation of the cells. Treatment with forskolin further enhanced the effect of leptin on both promoters, 


\begin{tabular}{|c|c|c|c|c|}
\hline WT & FFY & FYF & YFF & FFF \\
\hline L $\varnothing$ & L $\varnothing$ & L $\varnothing$ & L Ø & L $\ell$ \\
\hline
\end{tabular}

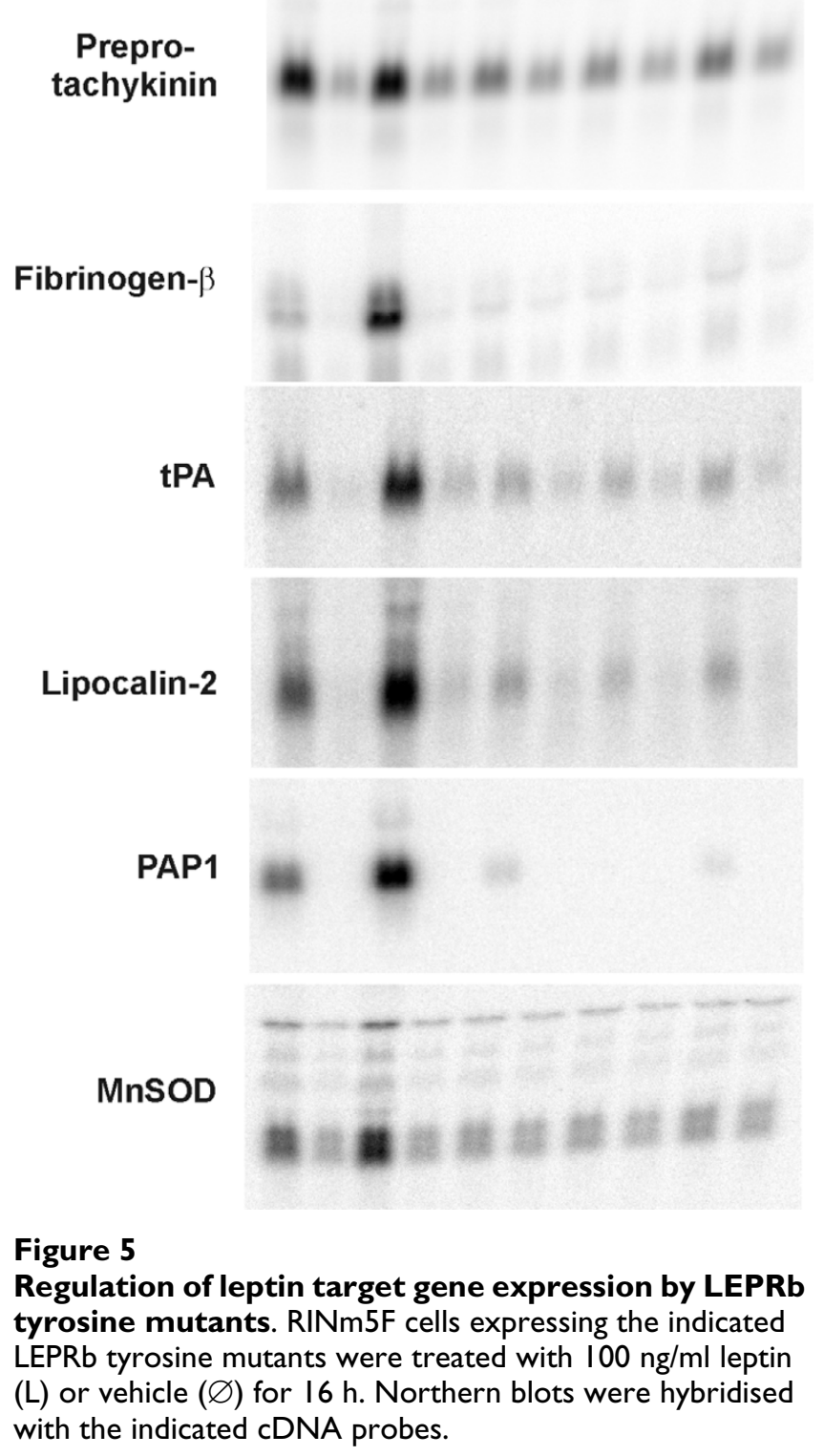

as previously observed for other leptin-regulated promoters in this cell line (proopiomelanocortin, neuropeptide $\mathrm{Y}$ and PAP [26]).

\section{Leptin increases caspase-like proteolytic activity in RINm5F cells}

To assess a possible cytotoxic effect of leptin on insulinproducing cells, we determined the effect of leptin treatment on the enzymatic activity of caspase 3 (and caspase 3-like proteases) as a key player in apoptosis induction. Exposure of RINm5F-LEPRb cells to leptin led to caspase 3 activation in a dose-dependent manner (Figure 8). Co-
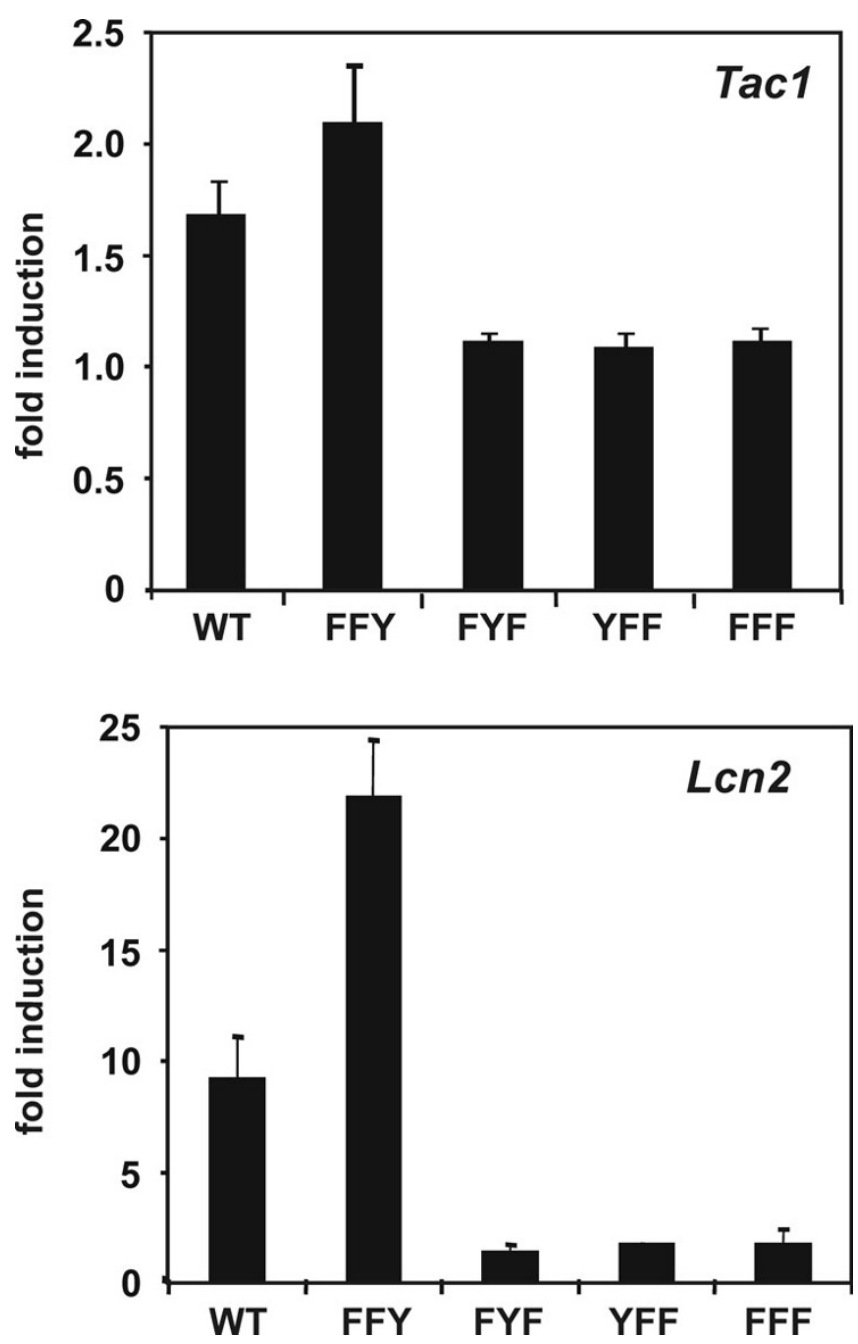

Figure 6

Regulation of Lcn2 and Tacl promoter by LEPRb mutants. HIT-TI 5 hamster insulinoma cells were transiently transfected with luciferase constructs driven by the rat Tacl promoter or the rat Lcn2 promoter, along with the indicated LEPRb expression plasmids. Twenty-four hours after transfection, the cells were treated with $100 \mathrm{ng} / \mathrm{ml}$ leptin or vehicle for 24 hours in serum-free medium. Luciferase activities were determined from duplicate wells and data were normalised to $\beta$-galactosidase activities. Data are expressed as fold stimulation by leptin relative to unstimulated cells. Bars reflect means $+/$ - SD of three independent experiments (except for FFY in the upper panel which is the mean of two).

administration of leptin with IL-1 $\beta$ revealed an additive effect of the cytokines. Leptin did not alter caspase activity in untransfected RINm5F cells (data not shown), indicating that the effect depended on the presence of LEPRb. As a positive control, the cells were also exposed to a mix of IL-1 $\beta$ and IFN $\gamma$ which is known to be proapoptotic for RINm5F cells [27]. In this direct comparison, the combination of IL-1 $\beta(50 \mathrm{u} / \mathrm{ml})$ and IFN $\gamma(50 \mathrm{ng} / \mathrm{ml})$ resulted in 

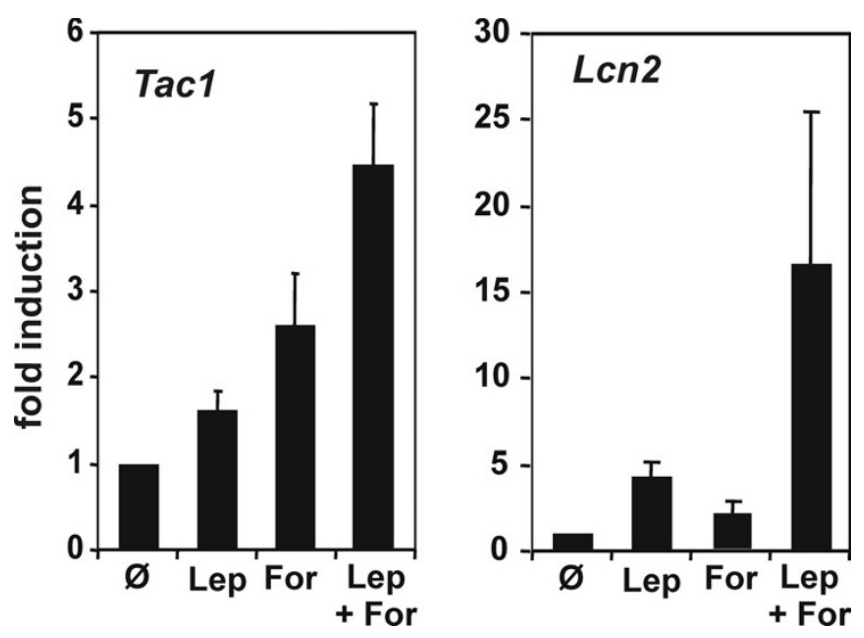

Figure 7

Synergistic regulation of Lcn2 and Tacl promoter activities by leptin and forskolin in PC-I 2 pheochromocytoma cells. PC- I 2 cells stably expressing LEPRb were transiently transfected with the Tacl or Lcn2 reporter gene constructs. Cells were left untreated or treated with leptin ( $100 \mathrm{ng} / \mathrm{ml})$ and/or forskolin $(10 \mu \mathrm{g} / \mathrm{ml})$ for 24 hours before lysis. Luciferase activities were determined from duplicate wells and data were normalised to $\beta$-galactosidase activities. Data are expressed as fold stimulation by the treatment relative to unstimulated cells. Results are means +/- SD of three (Tacl promoter) or four (Lcn2-promoter) independent experiments.

a stronger induction of caspase activity than IL-1 $1 \beta(50 \mathrm{u} /$ $\mathrm{ml})$ plus leptin $(100 \mathrm{ng} / \mathrm{ml})$.

\section{Discussion}

To gain insight into the gene regulatory effects of leptin that may contribute to its action on body weight regulation, screens for the identification of leptin-regulated genes have previously been performed in neuronal cell lines overexpressing LEPRb $[28,29]$. Here we have used the insulin-producing cell line RINm5F as a model system to characterise the transcriptional effects of leptin in pancreatic $\beta$-cells, one of the peripheral target cells of leptin. A striking result of this screen is that leptin induces the expression of several genes related to inflammatory conditions, including genes encoding acute phase response proteins (tPA, fibrinogen- $\beta$, lipocalin-2, PAP1), preprotachykinin and MnSOD. Moreover, some of these leptin-induced transcripts were also induced by IL-1 $\beta$, which is considered to be the most cytotoxic cytokine for $\beta$-cells $[30,31]$. These results reflect the molecular nature of leptin as a cytokine and are consistent with the hypothesis that high levels of leptin may play a role in the lowgrade inflammatory state associated with obesity [32].

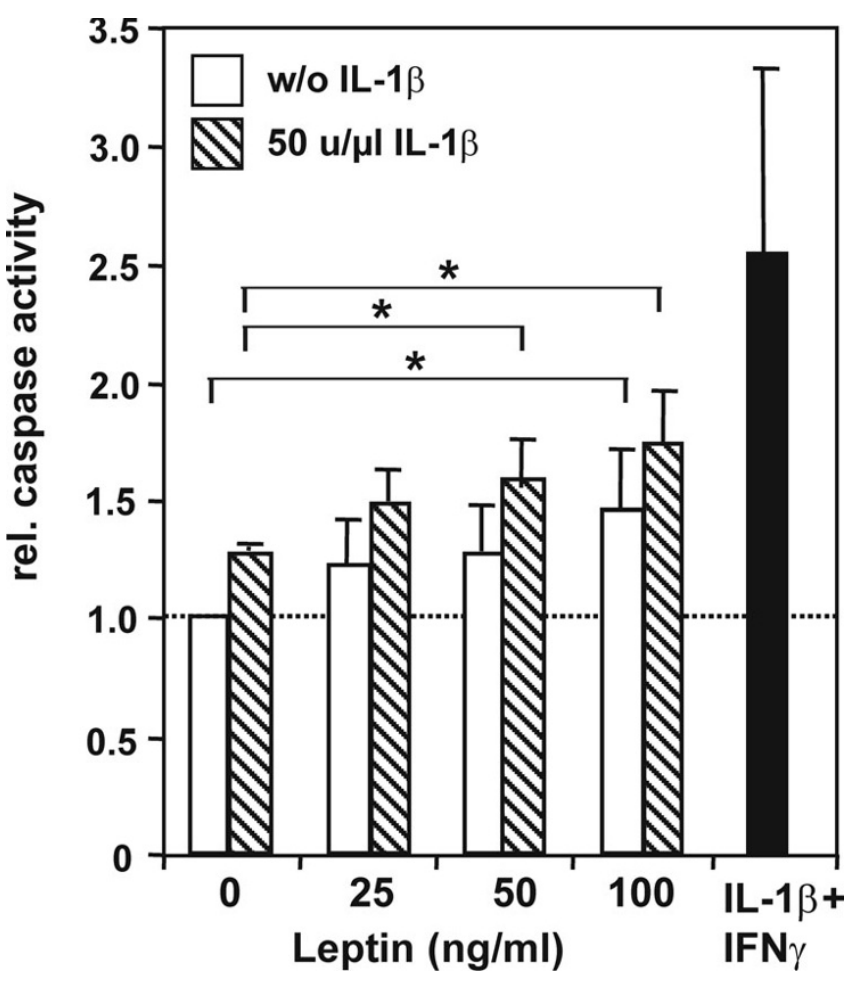

Figure 8

Leptin induces caspase activity in RINm5F cells. LEPRb-expressing RINm5F cells were exposed to the indicated concentrations of leptin for $48 \mathrm{~h}$, alone (open bars) or in combination with $50 \mathrm{u} / \mathrm{ml}$ IL-I $\beta$ (hatched). Alternatively, cells were treated with a mix of $50 \mathrm{u} / \mathrm{ml} \mathrm{IL-I} \beta$ and $50 \mathrm{ng} / \mathrm{ml}$ IFN $\gamma$. Caspase activity was determined in total cell lysates as the sequence-specific cleavage of a proluminescent DEVDaminoluciferin substrate. Data are expressed as fold stimulation by the cytokine treatment relative to unstimulated cells. Bars reflect means $+/$ - SD of 4 independent experiments. * $P$ $<0.05$, treated vs. untreated. The effect of $50 \mathrm{u} / \mathrm{ml} \mathrm{IL-I} \beta$ and $50 \mathrm{ng} / \mathrm{ml}$ IFN $\gamma$ was not significantly greater than that of $50 \mathrm{u} /$ $\mathrm{ml} \mathrm{IL}-\mathrm{I} \beta$ plus $100 \mathrm{ng} / \mathrm{ml}$ leptin $(P=0.058)$

What might be the role of these inflammation-related proteins in pancreatic islets? Of the genes listed in table 1, only Sod2 (encoding MnSOD) has been functionally studied in insulin-producing cells. Sod2 is strongly induced in many cells, including RINm5F, by IL- $1 \beta$ via binding of $\mathrm{NF \kappa B}$ to specific promoter elements [33]. Oxygen free radicals are generated in cytokine-stimulated $\beta$-cells, and overexpression of MnSOD, which inactivates mitochondrially derived oxygen free radicals, can prevent cytokineinduced apoptosis of $\beta$-cells [34-36]. Thus, upregulation of MnSOD by leptin is likely to have a protective effect on $\beta$-cells.

The role of the secreted acute phase proteins in $\beta$-cell inflammation has not yet been directly addressed. The product of the Pap gene (also known as PAP1 or Reg-2 in 
rat or Reg3 $\beta$ in mouse) has been designated "pancreatitisassociated protein" (PAP) because of its increased expression in rat pancreatic acinar cells in acute pancreatitis [37]. PAP1 belongs to a family of small secretory proteins that are related to REG1. The gene name Reg1 refers to regenerating pancreatic islets following partial pancreatectomy, where transcripts of Reg1 are significantly induced [38]. The REG1 protein is thought to act on pancreatic $\beta$-cells as an autocrine and/or paracrine factor and has been demonstrated to induce proliferation of $\beta$-cells and thereby to ameliorate the diabetes of $90 \%$ depancreatised rats and mice [39]. It is not known whether other members of the REG family share this ability, but PAP1 has been shown to act as an auto/paracrine neurotrophic factor on motoneurons [40]. Furthermore, PAP1 has anti-inflammatory effects in pancreatitis and inflammatory bowel disease [41], suggesting that it may also protect $\beta$-cells in islet inflammation. Interestingly, the PAP gene was found to be overexpressed in islets from a patient with recent-onset type 1 diabetes [42], indicating that its upregulation in islet inflammation is not restricted to rodents.

Lipocalin-2 (also known as 24p3, neutrophil gelatinaseassociated lipocalin NGAL, siderocalin, uterocalin, superinducible protein 24) has been identified as a very highly regulated transcript in many inflammatory conditions [43]. Lipocalin-2 sequesters bacterial siderophores and is a bacteriostatic agent contributing to the innate immune response [44]. Furthermore, the iron-free lipocalin-2 apoprotein can induce apoptosis of several cell types, including leukocytes, whereas iron-containing holo lipocalin-2 can prevent apoptosis $[45,46]$. The effect of lipocalin-2 on pancreatic $\beta$-cells has not yet been studied.

Fibrinogen- $\beta$ and tPA are classical acute phase plasma proteins that are predominately expressed in the liver [20]. It is unlikely that the enhanced expression of these proteins in pancreatic islets contributes significantly to their blood level, but local effects on fibrogenesis or fibrolysis may occur in insulitis. Similarly, the physiological significance of preprotachykinin expression is not clear. Preprotachykinin-1 is the precursor of substance $P$, a mediator of neurogenic inflammation in inflammatory diseases of the respiratory, gastrointestinal, and musculoskeletal systems [21]. RINm5F cells have previously been described to express Tac1 and to secrete substance P [47]. Interestingly, substance P has recently been implicated in the autoimmune diabetes of the NOD mouse model, because expression of the receptor for substance $\mathrm{P}$ (NK-1 receptor) was upregulated in the islets during development of insulitis [48]. However, preprotachykinin has been reported to be expressed in rat pancreatic islets only transiently during development, and the expression in RINm5F cells may reflect embryonal characteristics of this cell line [49].
In this study, we took advantage of the RINm5F insulinoma cell line as a model for pancreatic $\beta$-cells because cultured clonal cells provide a homogenous, well defined experimental system for array experiments. RINm5F cells have frequently been used to characterise the effect of cytokines on insulin-producing cells (e.g. [36,50]). We have recently shown that RINm5F cells expressing the long splicing variant of the leptin receptor (LEPRb) display the full range of leptin effects relevant for transcriptional regulation (activation of STAT1, STAT3, STAT5, ERK1/2; [18]. Importantly, most of the leptin-induced genes detected in the present screen have previously been identified in microarray analyses of animal models of type 1 or type 2 diabetes or in isolated rat pancreatic $\beta$-cells. Pap and Lcn2 were identified as the genes most strongly upregulated in islets from diabetic GK rats (a model for type 2 diabetes) [51]. Expression of Pap, Lcn2, and Sod2 (encoding MnSOD) was found to be increased in a mouse model of autoimmune diabetes [52]. Transcripts for tPA, fibrinogen- $\beta$ and MnSOD were induced by IL- $1 \beta$ in isolated rat $\beta$ cells [23]. Taken together, these results show that in RINm5F cells leptin induces a set of genes that is also expressed in $\beta$-cells in models of diabetes and $\beta$-cell destruction.

To sum up, the set of leptin-induced transcripts characterised here includes both mRNAs for protective (MnSOD, PAP1) as well as potentially cytotoxic proteins (lipocalin2 , preprotachykinin). Other well-characterised proinflammatory cytokines, such as the combination of IL-1 $\beta$ and IFN $\gamma$, are also known to induce defence-related genes [23]. Leptin did not induce the same genes as IFN $\gamma$, but both cytokines had the same costimulatory effect on certain IL$1 \beta$-induced transcripts (tPA, lipocalin-2, MnSOD; see Figure 3). After all, leptin induced caspase activation in RINm5F cells, strongly suggestive of a pro-apoptotic effect of leptin. Notably, the leptin concentration applied (100 $\mathrm{ng} / \mathrm{ml}$ ) is within the range of blood levels observed in obese humans [53]. However, more work is needed to establish whether the high levels of leptin in obesity have a protective effect or contribute to islet destruction in vivo.

Finally, we have employed LEPRb tyrosine/phenylalanine point mutants to provide an initial characterisation of the signalling pathway responsible for leptin's effect on gene expression in insulin-producing cells. For all genes under investigation, the induction by leptin was dependent on the presence of Tyr1138 which is embedded in a canonical box3 motif (Tyr-X-X-Gln). This result suggests that the effect of leptin requires the activation of STAT3 and/or STAT1. Some of the genes have previously been shown to be regulated by cytokines that activate STAT3, including MnSOD, fibrinogen- $\beta$, tPA and PAP1. We have previously identified Pap as a leptin-induced gene in rat PC12 pheochromocytoma cells, and have defined a STAT3-respon- 
sive promoter element $[25,26]$. Lcn2 is also known to be induced by cytokines that transmit their signal via activation of the JAK/STAT pathway (IL-9, IL-17, G-CSF). Our data show that induction of Lcn 2 by leptin depends on the presence of the Tyr1138 in LEPRb, suggesting that activation of STAT3 and/or STAT1 is required. However, the rat Lcn2 promoter contains no consensus STAT-binding element within the sequence tested in the reporter gene assay (search of the TRANSFAC database using the TESS software [54]). Similarly, no recognisable STAT3-binding site is present in the rat Tac1 promoter. Considering the delayed response of both the lipocalin-2 and preprotachykinin-1 mRNA to leptin, it appears likely that regulation of these genes occurs by an indirect mechanism.

\section{Conclusion}

The main result of our study is that leptin induces the expression of inflammation-related genes in RINm5F insulinoma cells, of which only PAP was already known as a leptin target gene. Several of these genes have also been described to be upregulated in animal models of diabetes (see discussion section), suggesting that this pattern of changes in gene expression reflects an inflammatory response of $\beta$-cells. The transcriptional effects of leptin required a functional box3 motif of the leptin receptor and are likely mediated via STAT3. Intriguingly, the effect of leptin on gene expression overlaps partially with that of IL-1 $\beta$, a cytokine acting via a completely different signalling pathway, but not with that of IFN $\gamma$, which activates STAT1. The observation that leptin synergises with IL-1 $\beta$ in caspase 3 induction is consistent with the proposed function of leptin as a modulator of immune and inflammatory responses.

\section{Methods \\ Cell culture, transient transfections and stably transfected cell lines}

Rat RINm5F insulinoma cells were grown in RPMI 1640 medium with L-glutamine, $10 \%(\mathrm{v} / \mathrm{v})$ fetal bovine serum, 100 units $/ \mathrm{ml}$ penicillin, and $100 \mathrm{mg} / \mathrm{ml}$ streptomycin at $37^{\circ} \mathrm{C}$ and $5 \% \mathrm{CO}_{2}$. HIT-T15 hamster insulinoma cells were cultivated under the same conditions except that $5 \%$ horse serum was added to the medium. Rat PC-12 pheochromocytoma cells stably expressing wild type LEPRb [25] were grown in DMEM supplemented with 5\% fetal calf serum and $10 \%$ horse serum on collagen-coated culture dishes. To obtain single cells for plating, cells were passed through a syringe with a 22-gauge needle. HIT-T15 and PC-12 cells were transiently transfected by the polyethylenimine method (Jet-PEI reagent; Polyplus-Transfection, Illkirch, France). The RINm5F cell line stably expressing wild type LEPRb has been described previously [18]. For stable expression of LEPRb tyrosine/phenylalanine mutants, the mutant cDNAs were subcloned from the pMET7 vector constructs [28] into the retroviral vector
pWZLNeo. These mutant constructs and the corresponding wild type receptor used in the experiments shown in Figures 4, 5, 6 contain a C-terminal myc-tag. Confluent RINm5F cells were infected with pWZL-Neo viruses, and infected cells were selected with geneticine sulphate (G418; $1 \mathrm{mg} / \mathrm{ml}$ ) as described before [18]. Cell surface expression of the different LEPRb constructs on RINm5F cells was measured using a mouse leptin-secreted alkaline phosphatase chimeric protein as described [28]. Murine leptin was purchased from PeproTech (London, UK), human IL-1 $\beta$ from Roche Diagnostics (Mannheim, Germany), and rat IFN $\gamma$ from Serotec (Düsseldorf, Germany).

\section{Isolation of RNA and differential hybridisation of high density CDNA filter arrays}

RINm5F-LepRb cells grown to $80 \%$ confluence were incubated in serum-free medium for $20 \mathrm{~h}$ before they were stimulated with murine leptin $(100 \mathrm{ng} / \mathrm{ml}$; PeproTech, London, UK) or left unstimulated for $16 \mathrm{~h}$. Total RNA was isolated using the RNeasy Midi Kit (Qiagen, Hilden, Germany), and poly-A+-RNA was prepared using oligo$(\mathrm{dT})_{30}$-coupled paramagnetic beads (Chemagen, Baesweiler, Germany). Complex cDNA probe was generated from $500 \mathrm{ng}$ of poly- $\mathrm{A}^{+}$-RNA by reverse transcription in the presence of $7.5 \mathrm{MBq}\left[\alpha^{3}{ }^{33} \mathrm{P}\right]-\mathrm{dCTP}(111 \mathrm{TBq} / \mathrm{mmol}$ Hartmann Analytics, Braunschweig, Germany) according to the protocol suggested by the manufacturer of the cDNA array (RZPD Berlin, Germany). The ${ }^{33}$ P-labelled single-stranded cDNA was hybridised to high density filter arrays that contained double-spotted, PCR-amplified cDNA inserts of the rat UniGene cDNA library (library 953, RZPD Berlin). This library comprises a set of 27,648 non-redundant rat cDNA clones provided by Bento Soares (University of Iowa). The filter were washed at high stringency (final wash in $150 \mathrm{mM} \mathrm{NaCl} / 15 \mathrm{mM} \mathrm{Na}$-citrate $\mathrm{pH}$ $7.0 / 0.1 \%$ SDS at $65^{\circ} \mathrm{C}$ ) and exposed for 72 hours to a phosphor storage screen (Fujifilm Imaging Plate BASMS2325, Fuji Photo Film, Japan). For probe removal, the filter was doused with boiling $0.1 \%$ SDS, $5 \mathrm{mM}$ phosphate buffer (ph 7.6) and left at room temperature under continuous agitation. This procedure was repeated and probe removal confirmed by exposure of an phosphor storage screen before rehybridization.

\section{Analysis of array data}

Signal intensities were evaluated using the AIDA ${ }^{\mathrm{TM}}$ software (AIDA Advanced Image Data Analyzer and AIDA Array Compare V 3.0; Raytest, Straubenhardt, Germany) as follows: integrated intensity values were determined for each spot and means of the two spots containing the same cDNA probe were calculated. For background correction, the signal intensity of the space between the spots was subtracted. To normalise for global intensity differences between the data sets, intensity values were divided by the intensity value of the spots containing $\beta$-actin cDNA. 
mRNA levels of $\beta$-actin were confirmed by Northern blot analysis to be unaffected by leptin treatment of RINm5F cells (data not shown). Only transcripts with an absolute signal intensity $\geq 1.0$ that showed $a \geq 2$.5-fold increase were considered relevant. The data presented in Table 1 and and Additional file 1 were obtained by successive hybridisation of the same filter array with the two complex cDNA probes derived from one experiment. Confirmatory Northern blot hybridisations (last column of table in Additional file 1) were done with RNA samples from independent experiments. Potentially interesting transcripts were arbitrarily selected for further analysis.

\section{Northern blot analysis}

Samples $(10 \mu \mathrm{g})$ of total RNA were separated by denaturing formaldehyde electrophoresis on $1 \%(\mathrm{w} / \mathrm{v})$ agarose gels and transferred by capillary blot onto positively charged nylon membranes (Hybond $\mathrm{N}+$; Amersham, Freiburg, Germany). Labelled probes were generated from the inserts of cDNA clones listed in Table 1 by random oligonucleotide priming. Murine cDNA clones were used to generate the probes for iNOS (inducible nitric oxide synthase; IMAGE clone 3583251, GenBank acc. No. BE372884) and IRF-1 (interferon regulatory factor 1, IMAGE clone 3600525, GenBank acc. No. BC003821). Blots were re-hybridised with other cDNA probes after probe removal by incubation with $0.5 \%$ SDS at $100^{\circ} \mathrm{C}$.

\section{Western blot analysis}

Stably transfected RINm5F cells were incubated in serumfree medium for $18-22 \mathrm{~h}$ before cytokines $(100 \mathrm{ng} / \mathrm{ml}$ leptin, $50 \mathrm{u} / \mathrm{ml} \mathrm{IL-1 \beta}$, or $25 \mathrm{ng} / \mathrm{ml}$ IFN $\gamma$ ) were added for $15 \mathrm{~min}$. Cells were washed with phosphate buffered saline and lysed in 1\% SDS, $20 \mathrm{mM}$ Tris-Cl pH 7.4 in a boiling water bath for $5 \mathrm{~min}$. Total cellular lysates were separated by SDS-PAGE ( $8 \%$ gels), blotted on-to nitrocellulose, and phosphorylation of specific proteins was analysed using the following antibodies (Cell Signaling Technology, Beverly, MA): anti-p(Y701)-STAT1, anti-p(Y705)-STAT3, anti$\mathrm{p}(\mathrm{Y} 694 / 699)-S T A T 5 A / B$, and anti-pT/pY-ERK1/2. Horseradish peroxidase-labelled anti-rabbit IgG (IgG-POD from Pierce Chemical Co., Rockford, IL) was used as the second antibody. Blots were re-used after stripping the primary antibody by incubation at room temperature for 20-30 min in $2 \%$ SDS, $50 \mathrm{mM}$ Tris-Cl, $150 \mathrm{mM} \mathrm{NaCl}$, pH7.4 in the presence of $100 \mathrm{mM} 2$ mercaptoethanol.

\section{Reporter gene assays}

A luciferase reporter construct containing the promoter region (-865 to +447; pSUB201-LPPT) of the rat preprotachykinin A gene (Tac1) was kindly provided by John Quinn, University of Liverpool, UK [55,56]. A 976-bp fragment of the rat lipocalin-2 (Lcn2) promoter region (930 to +46 , the first nucleotide of the cDNA sequence with GenBank acc. No. X13296 was defined as +1 ) was amplified with primers rLcn2-930for (5'-ATAGGTACCGGATGCCTTTTCAAGGGAGG-3') and rLcn2-Exon1rev (5'GACACCCAGGCCCATGGTTTCAGC-3') from rat genomic DNA. The PCR product was cloned into the pGL3basic vector (Promega, Madison, WI) using the engineered $K p n I$ site in the upstream primer and an endogenous $\mathrm{NcoI}$ site at the initiator codon, resulting in pGL3rLcn2(-930). DNA sequencing confirmed the identity of the PCR product and revealed a polymorphism in the rat Lcn2 promoter: a dinucleotide repeat (at -846 to -784) in our construct (from RINm5F genomic DNA) contained two more CA dinucleotides than the sequence (from the Sprague Dawley rat strain) available at the Genome Browser Gateway [57]. This polymorphic microsatellite has previously been used to map the rat Lcn2 gene [58]

HIT-T15 cells were seeded in six-well plates $\left(3.3-4.0 \times 10^{5}\right.$ cells per well) and transfected with $0.5 \mu \mathrm{g}$ of pSUB201LPPT or pGL3- rLen2(-930), along with $1.0 \mu \mathrm{g}$ of the $\beta$ galactosidase reporter control plasmid pSV $\beta$-gal (Promega) and $0.3 \mu \mathrm{g}$ of the pMET7-LEPRb expression plasmids [28]. $24 \mathrm{~h}$ or $48 \mathrm{~h}$ after transfection, the cells were stimulated with $100 \mathrm{ng} / \mathrm{ml}$ leptin for 22 hours in serum-free medium. Luciferase activities were determined from duplicate wells with the help of a commercial kit (Promega) and data were normalised to $\beta$-galactosidase activities. For assays of PC-12-L8 cells, cells from one 80 $\mathrm{cm}^{2}$-flask were seeded into 12 wells of collagen-coated sixwell plates and transfected with reporter gene plasmids as above. Fresh serum-containing medium was added the day after transfection, and cells were treated with leptin $(100 \mathrm{ng} / \mathrm{ml})$ and/or forskolin $(10 \mu \mathrm{M}) 24 \mathrm{~h}$ later. To avoid effects of differentiation, care was taken that the cells never reached confluence.

\section{Assay of caspase activity}

RINm5F cells were seeded in a white, non-translucent 96well plate $(10,000$ cells per well). The following day, cells were supplied with fresh medium and stimulated with cytokines as indicated. After incubation for $72 \mathrm{~h}$, DEVDdirected protease activity was determined from triplicate wells with the help of the Caspase-Glo ${ }^{\mathrm{TM}} 3 / 7$ Assay (Promega) which detects caspase activity based on the sequence-specific cleavage of a proluminescent caspase-3/ 7 DEVD-aminoluciferin substrate. The data were evaluated for statistical significance with the two-tailed Student's $t$ test, and the differences were considered significant at $P<0.05$.

\section{Abbreviations}

ERK, extracellular signal-regulated kinase; iNOS, inducible nitric oxide synthase; IL, interleukin; IRF1, interferon regulatory factor 1; LEPR, leptin receptor; MnSOD, manganese-dependent superoxide dismutase; PAP, pancreatitis-associated protein; STAT, signal transducer and 
activator of transcription; tPA, tissue-type plasminogen activator

\section{Authors' contributions}

PH carried out most of the experiments and drafted the manuscript. JZ established and characterized the stable RINm5F cell lines. SK and HK performed the reporter gene assays in HIT-T15 cells and carried out some of the Northern blots. SBL carried out the caspase assays and experiments with the PC12 cells. LZ constructed the LEPR expression clones and performed the binding assay. JT established the PC12 cell system and participated in the interpretation of the results and final editing of the manuscript. WB conceived of and planned this study and edited the manuscript. All authors read and approved the final manuscript.

\section{Additional material}

\section{Additional File 1}

Complete list of potentially leptin-induced transcripts identified by differential hybridisation. Leptin-induced cDNAs were identified in 16-h leptin-treated RINm5F cells as described in the methods section. This table lists all non-redundant $c D N A$ s that exhibit a signal intensity $\geq 1$ and were induced by $\geq 2.5$ fold.

Click here for file

[http://www.biomedcentral.com/content/supplementary/14712199-8-41-S1.pdf]

\section{Acknowledgements}

We are grateful to John Quinn (Liverpool, U.K.) for the gift of the Tacl promoter construct. This work was supported by a grant of the Deutsche Forschungsgemeinschaft (SFB 542 TP B3) to WB. Part of this work was funded by a grant from the FMRE-GSKE (to JT).

\section{References}

I. Friedman JM, Halaas JL: Leptin and the regulation of body weight in mammals. Nature 1998, 395:763-770.

2. Margetic S, Gazzola C, Pegg GG, Hill RA: Leptin: a review of its peripheral actions and interactions. Int J Obes Relat Metab Disord 2002, 26: I 407-I 433.

3. Kieffer TJ, Habener JF: The adipoinsular axis: effects of leptin on pancreatic beta-cells. Am J Physiol Endocrinol Metab 2000, 278:EI-EI4.

4. Emilsson V, Liu YL, Cawthorne MA, Morton NM, Davenport M: Expression of the functional leptin receptor mRNA in pancreatic islets and direct inhibitory action of leptin on insulin secretion. Diabetes 1997, 46:313-316.

5. Matarese G, Moschos S, Mantzoros CS: Leptin in immunology. J Immunol 2005, I74:3|37-3|42.

6. Peelman F, Iserentant $\mathrm{H}$, Eyckerman S, Zabeau L, Tavernier J: Leptin, immune responses and autoimmune disease. Perspectives on the use of leptin antagonists. Curr Pharm Des 2005, I I:539-548.

7. Lord GM, Matarese G, Howard JK, Baker RJ, Bloom SR, Lechler RI: Leptin modulates the $T$-cell immune response and reverses starvation-induced immunosuppression. Nature 1998, 394:897-90I.

8. Zhao AZ, Bornfeldt KE, Beavo JA: Leptin inhibits insulin secretion by activation of phosphodiesterase 3B. J Clin Invest 1998, 102:869-873.
9. Kieffer TJ, Heller RS, Leech CA, Holz GG, Habener JF: Leptin suppression of insulin secretion by the activation of ATP-sensitive K+ channels in pancreatic beta-cells. Diabetes 1997 , 46: 1087-1093.

10. Tartaglia LA: The leptin receptor. J Biol Chem 1997, 272:6093-6096.

II. Bjørbaek C, Uotani S, da Silva B, Flier JS: Divergent signaling capacities of the long and short isoforms of the leptin receptor. J Biol Chem 1997, 272:32686-32695.

12. Bahrenberg G, Behrmann I, Barthel A, Hekerman P, Heinrich PC, Joost HG, Becker W: Identification of the critical sequence elements in the cytoplasmic domain of leptin receptor isoforms required for Janus kinase/signal transducer and activator of transcription activation by receptor heterodimers. Mol Endocrinol 2002, 16:859-872.

13. Kulkarni RN, Wang ZL, Wang RM, Hurley JD, Smith DM, Ghatei MA, Withers DJ, Gardiner JV, Bailey CJ, Bloom SR: Leptin rapidly suppresses insulin release from insulinoma cells, rat and human islets and, in vivo, in mice. J Clin Invest 1997, 100:2729-2736.

14. Banks AS, Davis SM, Bates SH, Myers MG Jr: Activation of downstream signals by the long form of the leptin receptor. J Biol Chem 2000, 275: I 4563-14572.

15. Tanabe K, Okuya S, Tanizawa Y, Matsutani A, Oka Y: Leptin induces proliferation of pancreatic beta cell line MIN6 through activation of mitogen-activated protein kinase. Biochem Biophys Res Commun 1997, 241:765-768.

16. Morton NM, Emilsson V, de Groot P, Pallett AL, Cawthorne MA: Leptin signalling in pancreatic islets and clonal insulin-secreting cells. J Mol Endocrinol 1999, 22:173-184.

17. Seufert J, Kieffer TJ, Habener JF: Leptin inhibits insulin gene transcription and reverses hyperinsulinemia in leptin-deficient ob/ob mice. Proc Natl Acad Sci USA 1999, 96:674-679.

18. Hekerman P, Zeidler J, Bamberg-Lemper S, Knobelspies H, Lavens D, Tavernier J, Joost HG, Becker W: Pleiotropy of leptin receptor signalling is defined by distinct roles of the intracellular tyrosines. FEBS J 2005, 272:109-1 19.

19. Seufert J: Leptin effects on pancreatic beta-cell gene expression and function. Diabetes 2004, 53(SuppI I):SI52-I58.

20. Gabay C, Kushner I: Acute-phase proteins and other systemic responses to inflammation. N Engl ] Med 1999, 340:448-454.

21. O'Connor TM, O'Connell J, O'Brien DI, Goode T, Bredin CP, Shanahan $\mathrm{F}$ : The role of substance $\mathbf{P}$ in inflammatory disease. J Cell Physiol 2004, 201:167-180.

22. Dougall WC, Nick HS: Manganese superoxide dismutase: a hepatic acute phase protein regulated by interleukin-6 and glucocorticoids. Endocrinology 1991, 129:2376-2384.

23. Cardozo AK, Kruhøffer M, Leeman R, Orntoft T, Eizirik DL: Identification of novel cytokine-induced genes in pancreatic betacells by high-density oligonucleotide arrays. Diabetes 200I, 50:909-920.

24. Bjørbaek C, Lavery HJ, Bates SH, Olson RK, Davis SM, Flier JS, Myers MG Jr: SOCS3 mediates feedback inhibition of the leptin receptor via Tyr985. J Biol Chem 2000, 275:40649-40657.

25. Waelput W, Verhee A, Broekaert D, Eyckerman S, Vandekerckhove J, Beattie JH, Tavernier J: Identification and expression analysis of leptin-regulated immediate early response and late target genes. Biochem J 2000, 348:55-6I.

26. Broekaert D, Eyckerman S, Lavens D, Verhee A, Waelput W, Vandekerckhove J, Tavernier J: Comparison of leptin- and interleukin-6-regulated expression of the rPAP gene family: evidence for differential co-regulatory signals. Eur Cytokine Netw 2002, 13:78-85.

27. Saldeen J: Cytokines induce both necrosis and apoptosis via a common Bcl-2-inhibitable pathway in rat insulin-producing cells. Endocrinology 2000, 141:2003-2010.

28. Eyckerman S, Broekaert D, Verhee A, Vandekerckhove J, Tavernier J: Identification of the Y985 and YI077 motifs as SOCS3 recruitment sites in the murine leptin receptor. FEBS Lett 2000, 486:33-37.

29. White DW, Zhou J, Stricker-Krongrad A, Ge P, Morgenstern JP, Dembski M, Tartaglia LA: Identification of leptin-induced transcripts in the mouse hypothalamus. Diabetes 2000, 49: $1443-1450$.

30. Mandrup-Poulsen $\mathrm{T}$ : The role of interleukin- $\mathrm{I}$ in the pathogenesis of IDDM. Diabetologia 1996, 39: 1005-1029. 
31. Donath MY, Storling J, Maedler K, Mandrup-Poulsen T: Inflammatory mediators and islet beta-cell failure: a link between type $\mathrm{I}$ and type 2 diabetes. J Mol Med 2003, 8I:455-470.

32. Loffreda S, Yang SQ, Lin HZ, Karp CL, Brengman ML, Wang DJ, Klein AS, Bulkley GB, Bao C, Noble PW, Lane MD, Diehl AM: Leptin regulates proinflammatory immune responses. FASEB J 1998, 1 2:57-65.

33. Darville MI, Ho YS, Eizirik DL: NF-kappaB is required for cytokine-induced manganese superoxide dismutase expression in insulin-producing cells. Endocrinology 2000, I4 I: I53-162.

34. Hohmeier HE, Thigpen A, Tran VV, Davis R, Newgard CB: Stable expression of manganese superoxide dismutase (MnSOD) in insulinoma cells prevents IL-I beta- induced cytotoxicity and reduces nitric oxide production. I Clin Invest 1998, | 0 |: | 81 | - | 820.

35. Bertera S, Crawford ML, Alexander AM, Papworth GD, Watkins SC, Robbins PD, Trucco M: Gene transfer of manganese superoxide dismutase extends islet graft function in a mouse model of autoimmune diabetes. Diabetes 2003, 52:387-393.

36. Azevedo-Martins AK, Lortz S, Lenzen S, Curi R, Eizirik DL, Tiedge M: Improvement of the mitochondrial antioxidant defense status prevents cytokine-induced nuclear factor-kappaB activation in insulin-producing cells. Diabetes 2003, 52:93-I0I.

37. lovanna J, Orelle B, Keim V, Dagorn JC: Messenger RNA sequence and expression of rat pancreatitis-associated protein, a lectin-related protein overexpressed during acute experimental pancreatitis. J Biol Chem I99I, 266:24664-24669.

38. Terazono K, Yamamoto H, Takasawa S, Shiga K, Yonemura $Y$, Tochino $\mathrm{Y}$, Okamoto $\mathrm{H}$ : A novel gene activated in regenerating islets. J Biol Chem 1988, 263:2III-2II4.

39. Watanabe T, Yonemura Y, Yonekura H, Suzuki Y, Miyashita H, Sugiyama K, Moriizumi S, Unno M, Tanaka O, Kondo H, Bone AJ, Takasawa $\mathrm{S}$, Okamoto $\mathrm{H}$ : Pancreatic beta-cell replication and amelioration of surgical diabetes by Reg protein. Proc Natl Acad Sci USA 1994, 91 :3589-35892.

40. Nishimune H, Vasseur S, Wiese S, Birling MC, Holtmann B, Sendtner $M$, lovanna JL, Henderson CE: Reg-2 is a motoneuron neurotrophic factor and a signalling intermediate in the CNTF survival pathway. Nat Cell Biol 2000, 2:906-914.

4I. Gironella M, lovanna JL, Sans M, Gil F, Penalva M, Closa D, Miquel R, Pique JM, Panes J: Anti-inflammatory effects of pancreatitis associated protein in inflammatory bowel disease. Gut 2005, 54: $1244-1253$

42. Gurr W, Yavari R, Wen L, Shaw M, Mora C, Christa L, Sherwin RS: A Reg family protein is overexpressed in islets from a patient with new-onset type I diabetes and acts as T-cell autoantigen in NOD mice. Diabetes 2002, 51 1:339-346.

43. Kjeldsen L, Cowland JB, Borregaard N: Human neutrophil gelatinase-associated lipocalin and homologous proteins in rat and mouse. Biochim Biophys Acta 2000, I 482:272-283.

44. Goetz DH, Holmes MA, Borregaard N, Bluhm ME, Raymond KN, Strong RK: The neutrophil lipocalin NGAL is a bacteriostatic agent that interferes with siderophore-mediated iron acquisition. Mol Cell 2002, 10:1033-1043.

45. Devireddy LR, Teodoro JG, Richard FA, Green MR: Induction of apoptosis by a secreted lipocalin that is transcriptionally regulated by IL-3 deprivation. Science 200I, 293:829-834.

46. Devireddy LR, Gazin C, Zhu X, Green MR: A cell-surface receptor for lipocalin $24 \mathrm{p} 3$ selectively mediates apoptosis and iron uptake. Cell 2005, I 23:1293-I305.

47. McGregor GP, Hartel R, Fehmann HC, Lankat-Buttgereit B, Göke B Göke R, Voigt K: Characterisation of the expression and posttranslational processing of the preprotachykinin-I gene and the regulated release of tachykinins by the RINm5F cell-line. FEBS Lett 1992, 3 I 2: 187-191.

48. Persson-Sjogren S, Lejon K, Holmberg D, Forsgren S: Expression of the NK-I receptor on islet cells and invading immune cells in the non-obese diabetic mouse. J Autoimmun 2005, 24:269-279.

49. McGregor GP, Hartel R, Haberberger R, Kummer W, Voigt K: Preprotachykinin-A gene expression occurs transiently in the developing rat endocrine pancreas and can be regulated in RINm5F cells. Endocrinology 1995, I36:2538-2546.

50. Kim MJ, Ryu GR, Kang JH, Sim SS, Min do S, Rhie DJ, Yoon SH, Hahn SJ, Jeong IK, Hong KJ, Kim MS, Jo YH: Inhibitory effects of epicatechin on interleukin- I beta-induced inducible nitric oxide synthase expression in RINm5F cells and rat pancreatic islets by down-regulation of NF-kappaB activation. Biochem Pharmacol 2004, 68: I775-I785

51. Homo-Delarche F, Calderari S, Irminger JC, Gangnerau MN, Rickenbach K, Dolz M, Halban P, Portha B, Serradas P: Islet inflammation and fibrosis in a spontaneous model of type 2 diabetes, the GK rat. Diabetes 2006, 55:|625-1633.

52. Matos M, Park R, Mathis D, Benoist C: Progression to islet destruction in a cyclophosphamide-induced transgenic model: a microarray overview. Diabetes 2004, 53:2310-2321.

53. Considine RV, Sinha MK, Heiman ML, Kriauciunas A, Stephens TW Nyce MR, Ohannesian JP, Marco CC, McKee LJ, Bauer TL, Caro JF: Serum immunoreactive-leptin concentrations in normalweight and obese humans. N Engl J Med 1996, 334:292-295.

54. TESS - String Search Page [http://www.cbil.upenn.edu/tess]

55. Fiskerstrand CE, Newey P, Ebrahimi B, Gerrard L, Harrison P, McGregor GP, Quinn JP: Novel cell lines for the analysis of preprotachykinin A gene expression identify a repressor domain 3' of the major transcriptional start site. Biochem J 1999, 34 I:847-852

56. Harrison PT, Dalziel RG, Ditchfield NA, Quinn JP: Neuronal-specific and nerve growth factor-inducible expression directed by the preprotachykinin-A promoter delivered by an adenoassociated virus vector. Neuroscience 1999, 94:997-1003.

57. UCSC Genome Browser [http://genome.ucsc.edu]

58. Chen K, Shepel LA, Stoesz SP, Brasic GM, Gould MN: Genetic mapping of the rat Lon2 gene to chromosome 3. Cytogenet Cell Genet 1999, 87:273-274.
Publish with Biomed Central and every scientist can read your work free of charge

"BioMed Central will be the most significant development for disseminating the results of biomedical research in our lifetime. "

Sir Paul Nurse, Cancer Research UK

Your research papers will be:

- available free of charge to the entire biomedical community

- peer reviewed and published immediately upon acceptance

- cited in PubMed and archived on PubMed Central

- yours - you keep the copyright
BioMedcentral 